\title{
Professional psycholinguistic training of speech therapists in higher education
}

\author{
Olga Koshcheyeva ${ }^{1}$,Vladimir Kryuchkov ${ }^{1 *}$, Natalia Maltseva $^{2}$ and Olga Yakunina ${ }^{1}$ \\ ${ }^{1}$ Saratov State University, Department of Speech Therapy and Psycholinguistics, 410012 \\ Saratov, Russia \\ ${ }^{2}$ Saratov State University, Department of Romance and Germanic Languages and Translation \\ Studies, 410012 Saratov, Russia
}

\begin{abstract}
The article discusses the psycholinguistic training of speech therapists in present-day higher education. We argue the importance of psycholinguistic training of undergraduate and graduate students majoring in speech therapy and describe the educational design and implementation of psycholinguistic training at the Faculty of Pedagogical and Special Needs Education of Saratov National Research State University.
\end{abstract}

It was not until fairly recently that psycholinguistics as a scientific discipline has been included into the university curriculum for would-be speech therapists. It happened in recent decades, when prominent foreign and Russian scholars, such as T.V. Akhutina, T.V. Chernigovskaya, Noam Chomsky, R.M. Frumkina, I.N. Gorelov, V.V. Krasnykh, A.A. Leontiev, Stephen Pinker, L.V. Sakharny, A.M. Shakhnarovich, S.N. Tseytlin, T.N. Ushakova, A.A. Zalevskaya, N.I. Zhinkin, I.A. Zimniaya, and many others, laid the foundation for the field of psycholinguistics. Different psycholinguistic concepts have developed the structure of the discipline, its content, nuclear and peripheral segments, accompanied by the variety of research methods.

The University of Saratov has a long-standing commitment to psycholinguistics.

The academic scene was greatly influenced by Ilya Gorelov - Russian philologist, professor of the Department of German Philology of Saratov State University in 1982-1999, one of the largest Russian experts in psycholinguistics. His research interests included the problems of ontogenesis of consciousness, bilingualism, and non-verbal communication.

I.N. Gorelov was also an extraordinary teacher, whose expertise fuelled the advancement of psycholinguistic ideas. Professor Konstantin Sedov, his student and successor, worked towards the theoretical and methodological basis for building a framework of professional psycholinguistic training of speech therapists at the Department of Speech Therapy and Psycholinguistics at Saratov State University. He possessed a broad understanding of the content and structure of psycholinguistics, which in his opinion could be divided into general and specific psycholinguistics, namely social psycholinguistics and developmental psycholinguistics. Within general psycholinguistics, he distinguished the following sections: "psycholinguistics of thinking, psycholinguistics of consciousness, psycholinguistics of

\footnotetext{
* Corresponding author: vpks1@yandex.ru
} 
discourse and neuropsycholinguistics" [1, p. 8]. Such a broad understanding of psycholinguistics matches the spirit of modern speech therapy, its both directions pedagogical and medical. By V.P. Glukhov's fair account, "the professional purpose of speech therapy is not limited to eliminating the shortcomings (disorders) of speech; the main task of speech therapy practice is the formation of linguistic (speech) ability - the ability to carry out speech activity"[2, p. 8].

At present, the professional competence of a speech therapist is largely determined by the level of his/her psycholinguistic training. Now it is completely obvious that a specialist in the prevention, diagnosis and remediation of speech disorders needs to understand the underlying mechanisms of speech and use them while addressing the issues of language difficulties. The general system of speech therapy training must necessarily include the step-by-step learning about the most important achievements in the field of general, developmental, and social psycholinguistics. In both theoretical and practical terms, psycholinguistic knowledge is the foundation of speech therapy work.

The Department of Speech Therapy and Psycholinguistics of Saratov National Research State University named after N.G. Chernyshevsky follows the scientific and methodological traditions of the Saratov psycholinguistic school and implements the comprehensive model for the study of the psycholinguistic foundations of speech therapy within the framework of undergraduate and graduate programs in the field of Special Needs Education (Defectology). This model was further developed in the new federal state educational standard in its close coordination with professional activity - professional standards.

In what follows we present the substantive aspects of this model in more detail.

The structure of the module for the psycholinguistic training of speech therapists includes not only psycholinguistics itself, but also other theoretical and applied disciplines, where the psycholinguistic component is closely related to the issues of the professional formation of a specialist in children's speech in its normative and deviating development options.

The model being implemented stresses the importance of the subjects of Psycholinguistics and Language Acquisition (Developmental Psycholinguistics) at the first stage of higher education - the undergraduate level, since they introduce basic principles of the speech theory (language, speech and thinking relations; speech production and reception, speech behavior, etc.), and the laws governing the human language competence. This knowledge enables to identify primary and secondary speech disorders, making right diagnoses, and planning effective intervention programs. The inclusion of these subjects in the speech therapist tuition plan allows bachelors to form scientific ideas about the underlying mechanisms of speech activity and to exclude a superficial, formal attitude to the diagnosis and correction of speech disorders in the future.

In the second year, the discipline of Speech Technique is studied, which is not limited by the technical aspects of speech, but also illustrates the psycholinguistic theory of speech, provides for the skills development in respect to individual psychological control of voice, diction, intonation, logic in accordance with socio-psychological communication conditions.

Increasing migration processes bring along the importance of ethnolinguistic and sociolinguistic fields of study. In Saratov region this problem has a resonance, since the region is increasingly becoming multinational, multilingual, which transforms intervention strategies. Every year, students from other republics: Kazakhstan, Azerbaijan, Tajikistan enter the degree programs in speech therapy in SSU, which also increases the role of the ethnolinguistic component in the training of a speech therapist.

At senior undergraduate courses, which are dominated by professional speech therapy disciplines, the psycholinguistic aspects of speech are studied in connection with their practical application and are included in such Subjects as Speech Assessment Technology, Speech-Language Therapy, Speech Therapy Technologies, Speech Therapy for Children with Sensory, Motor, and Intellectual Deficiency, Psychological and Language Development 
of Young Children, Speech Therapy in Preschool Educational Institutions, Speech Therapy at School and others.

At this stage the concentric teaching approach is pivotal, which allows to expand and clarify the students' understanding of psycholinguistic ideas of L.S. Vygotsky, N.I. Zhinkin, I.N. Gorelov, K.F. Sedov and other scholars gradually, and helps to generate individual and differentiated approaches to the diagnosis and remediation of speech disorders.

Let us present examples of the implementation of this approach in the framework of the above mentioned disciplines.

The course of Psycholinguistics covers the laws of functioning of phonetic, lexical and grammatical units in the human mind. In the course of practical activity such awareness is necessary, for example, for speech elicitation in children with severe systemic and motor disorders (delayed speech development, alalia, dysarthria). It has already been proven that the effect of synesthesia, discovered and studied by A.R. Luria, A.P. Zhuravlev, E.I. Krasnikova and other scholars, can effectively ring up the majority of simple sounds of the native language in non-speaking young children, and develop their phonemic perception. The main task of a speech therapist in working with young children is to help "materialize" abstract phonemes into sound and visual images and sensations that are understandable to children, and, further down the line, form primary robust representations which will enable the child to distinguish linguistic units of various levels.

When students learn about the lexical and grammatical structure of speech, the organization of the mental lexicon and individual grammar system comes to the fore. Any hasty or inconsistent introduction of new language may hamper speech therapy efforts to instill primary grammar and result into the child's difficulty or inability to remember new lexemes. The psycholinguistic method of free associations has theoretical and practical significance, bringing to light the fact that in our minds words are bound by associative connections that reflect individual social experience (nationality, profession, age). Awareness of the mental lexicon's inner structure, that is, the grouping of words in our minds into associative (semantic) fields that have a center (where the connections between words are stronger), periphery (where the connections are weaker) and the weakest connections based on phonetic similarities govern the methodological choice of presenting and systematizing vocabulary material in speech therapy practice.

The psycholinguistic approach to the study of derivation and lexical morphology also gives insights into the mechanisms of children's novel words and the specifics of derivative semantics embedded in the internal form of a word.

At the morphological level, when developing syntactic, inflectional, and derivational models, it is important to take into account the psycholinguistic patterns of their acquisition: starting from systemic, global rules to normative use, from prototypical models to all kinds of exceptions and irregular variations.

The discourse approach in the training schedule of a prospective speech therapist involves mastering the psycholinguistic norms of textuality and the skills of receptive and productive non-verbal communication.

While studying the psycholinguistic concept of speech and language students have to learn about the functioning of lexical storage and retrieval in human mind which is fundamental for the differentiated and individualized approach to speech therapy methods. Treating some disorders, first of all, of phonetic origin - dyslalia, dysarthria, etc. - requires addressing minimal language units (individual sounds and syllables) first, followed by the transition to the whole word stage. While dealing with insufficient grammar in young children as well as in cases of specific language impairment, it is advisable to use the inverse method, moving from large units to smaller ones.

Updated views and observations, resonant discoveries in the field of psycholinguistics are part of all speech therapy disciplines teaching program. The study of the classification of 
speech disorders and diagnostic process at the undergraduate level emphasizes the necessity to correlate the milestones of verbal communication development in normal population with the signs and manifestations of possible speech dysfunctions.

Thus, at the first level of higher education, future speech therapists study the general issues of psycholinguistics, but at the same time they master the skills of using this knowledge in practice. Psycholinguistic disciplines or the psycholinguistic components in the applied sciences contribute to a more accurate diagnosis of primary and secondary disorders and their effective treatment.

At the undergraduate level, students master the following basic psycholinguistic knowledge: understanding the interrelations of speech and other higher mental functions; psycholinguistic aspects of phonetics, vocabulary and grammar; mechanisms, stages of speech perception and production under normal and pathological conditions; ways of transmitting information in the course of normal development and various variants of dysontogenesis; age-related aspects of speech (ontolinguistics); ways to apply their psycholinguistic knowledge in the process of prevention, diagnosis and remediation of speech disorders.

The second stage of higher education - master's program - involves students' independent research, deepening knowledge in theory and practice of speech therapy, as well as studying related disciplines, including psycholinguistics. In accordance with this, the study of the psycholinguistic foundations of speech therapy is becoming more sophisticated and modified. The curriculum of the Master's degree program in Speech-Language Therapy majoring in Special Needs Education (Defectology) includes subjects that further explore the psycholinguistic aspects of speech: Fundamentals of Onto- and Neurolinguistics, SpeechLanguage Therapy Service to Bilingual Children, Linguistic Problems of Special Pedagogy and Psychology, Functional Asymmetry of the Brain and Left-handedness, Early Diagnosis, Treatment and Prevention of Speech Disorders, Speech-Language Therapy Service to Children with Complicated Developmental Disorders, Formation of Writing Competence in Children with Disabilities, etc.

Master's programs in a speech therapist training are aimed at studying the mechanisms and specifics of the language acquisition and functioning in various communicative conditions, in various social settings (bilingualism, ethnocultural situation, etc.), with various developmental disadvantages.

In Tables 1 and 2 below we present the main tasks of the psycholinguistic unit, implemented at the undergraduate and graduate levels, respectively.

Table 1. Model for the inclusion of psycholinguistic tasks into the curriculum for undergraduates, field of study: Special Needs Education (Defectology), major: Speech-Language Therapy

\begin{tabular}{|l|l|}
\hline Subject & $\begin{array}{l}\text { Main psycholinguistic tasks mastered in the course of } \\
\text { study }\end{array}$ \\
\hline Psycholinguistics & psycholinguistic aspects of language units of various \\
levels and their functioning in the human mind \\
stages of speech production and reception; \\
mechanisms of language performance \\
methods of transmitting information in speech \\
main aspects of speech and thinking interrelation
\end{tabular}




\begin{tabular}{|c|c|}
\hline $\begin{array}{c}\text { Speech-Language Therapy, } \\
\text { Speech Therapy Technologies }\end{array}$ & $\begin{array}{c}\text { psycholinguistic foundations of communication } \\
\text { nature of language dysfunctions in various language } \\
\text { impairments } \\
\text { mapping the milestones of verbal communication } \\
\text { development with the manifestations of various speech } \\
\text { dysfunctions } \\
\text { psycholinguistic approaches to the making of } \\
\text { diagnoses and speech therapy intervention }\end{array}$ \\
\hline $\begin{array}{l}\text { Speech Therapy for Children } \\
\text { with Sensory, Motor, and } \\
\text { Intellectual Deficiency }\end{array}$ & $\begin{array}{l}\text { linguistic and communicative units in primary and } \\
\text { secondary speech disorders } \\
\text { psycholinguistic approaches to the diagnosis and } \\
\text { remediation of speech disorders of children with } \\
\text { sensory, motor and intellectual deficiency }\end{array}$ \\
\hline $\begin{array}{l}\text { Psychological and Language } \\
\text { Development of Young } \\
\text { Children, Speech Therapy in } \\
\text { Preschool Educational aspect of the functioning of linguistic and } \\
\text { Institutions, Speech Therapy at } \\
\text { School }\end{array}$ & $\begin{array}{c}\text { psycholinguistic foundations of speech therapy } \\
\text { services for children of different ages; } \\
\text { psycholinguistic mechanisms of writing }\end{array}$ \\
\hline
\end{tabular}

Table 2. Model for the inclusion of psycholinguistic tasks into the curriculum for graduates, field of study: Special Needs Education (Defectology), major: Speech-Language Therapy

\begin{tabular}{|c|c|}
\hline Subject & $\begin{array}{l}\text { Main psycholinguistic tasks mastered in the course of } \\
\text { study }\end{array}$ \\
\hline $\begin{array}{l}\text { Fundamentals of Onto- and } \\
\text { Neurolinguistics }\end{array}$ & $\begin{array}{l}\text { brain organization of speech } \\
\text { language acquisition in different social contexts } \\
\text { (ethno-and socio-cultural factors affecting language } \\
\text { development) } \\
\text { psycholinguistic research into language acquisition } \\
\text { use of neurolinguistic data in human language } \\
\text { behavior analysis }\end{array}$ \\
\hline $\begin{array}{l}\text { Speech-Language Therapy } \\
\text { Service to Bilingual Children }\end{array}$ & $\begin{array}{l}\text { language acquisition mechanisms in the situation of } \\
\text { bilingualism } \\
\text { psycholinguistic research into speech-language } \\
\text { therapy for bilingual children }\end{array}$ \\
\hline $\begin{array}{l}\text { Early Diagnosis, Treatment } \\
\text { and Prevention of Speech } \\
\text { Disorders, Speech-Language } \\
\text { Therapy Service to Children } \\
\text { with Complicated } \\
\text { Developmental Disorders, } \\
\text { Formation of Writing } \\
\text { Competence in Children with } \\
\text { Disabilities }\end{array}$ & $\begin{array}{l}\text { research into the psycholinguistic aspects of the } \\
\text { prevention, diagnosis and remediation of speech } \\
\text { disorders }\end{array}$ \\
\hline \begin{tabular}{lr}
\multicolumn{1}{c}{ Linguistic $\begin{array}{r}\text { Problems } \\
\text { Special Pedagogy }\end{array}$} \\
Psychology
\end{tabular} & $\begin{array}{l}\text { the formation of a holistic view on the interrelations of } \\
\text { linguistics, special needs psychology and defectology } \\
\text { mastering the practical skills to implement the } \\
\text { linguistic aspects of the study and correction of } \\
\text { developmental disorders }\end{array}$ \\
\hline
\end{tabular}


Functional Asymmetry of the Brain and Left-handedness functional brain asymmetry and its impact on the mental functions performance in right- and left-handed populations (children)

skills and techniques for identifying and remediation of speech disorders caused by left-handedness

Thus, the model of psycholinguistic training of present-day speech therapists implemented at Saratov State University includes, at the first stage (the undergraduate level), the introduction into the basics of general psycholinguistics, developmental psycholinguistics, onto- and sociolinguistics, as well as mastering of psycholinguistic diagnosis-making and remediation of speech disorders within the framework of special needs speech therapy professional disciplines; at the second stage of higher education (the graduate level) increased attention is paid to the independent scientific and methodological work of the graduates towards intervention strategies dealing with different language disorders, and mastering the skills of speech-language therapy using psycholinguistic data.

\section{References}

1. K.F. Sedov, Neuropsycholinguistics (Labyrinth, Moscow, 2007)

2. V.P. Glukhov, Ontogenesis of speech activity. Lecture Course (MSPU, 2017) 